\title{
ELECTROCHEMICAL EVIDENCES OF THE PROTECTION EFFICIENCY OF PROPARGYL ALCOHOL ON LOW-CARBON STEEL IN ETHANOLIC SOLUTIONS BY ELECTRICAL CONDUCTIVITY MEASURES
}

Reinaldo Simões Gonçalves and Natalie Maria Coradini Departamento de Química - Centro de Ciências Naturais e Exatas UFSM - Santa Maria, RS.

\section{SUMMARY}

It is shown that electrical conductivity measurement is a good method to characterize corrosion processes that occur on low-carbon steel in ethanolic solutions. Different aggressive conditions were tested by changing the water content in distilled ethanol and by adding acetic acid. Propargyl alcohol inhibits the corrosion reaction. The specific conductivity of the solution decreases in the presence of propargyl alcohol for varying levels of aggressiveness. In dilute acetic acid ethanolic solutions, the protection efficiency was better in $1.0 \mathrm{mM}$ propargyl alcohol than in the other concentrations.

RESUMO

GONÇALVES, R.S.; CORADINI, N.M. 1994 - Evidências eletroquímicas da eficiência de proteção do álcool propargílico sobre o aço-carbono em soluções etanólicas, por medidas de condutividade elétrica.

Neste trabalho é apresentado que a medida da condutividade elétrica da solução é um bom método para caracterizar os processos de corrosão que ocorrem sobre o aço-carbono em meio etanólico. Diferentes condições agressivas foram testadas modificando-se o conteúdo de água no etanol destilado e, por adição de ácido acético. 0 álcool propargílico inibe a reação de corrosão. A condutividade específica da solução diminui na presença de álcool propargílico mesmo em diferentes níveis de agressividade. Em soluções etanólicas diluídas de ácido acético, a eficiência de proteção foi melhor em uma solução $1,0 \mathrm{mM}$ de álcool propargílico, do que nas outras concentrações. 
INTRODUCTION

Ethanol derived from fermentation of sugar-cane is succesfully used as a substitute for gasoline in Brazil(1). It is economically

produced from renewable energy sources. The primary goal of this substitution is aimed at reducing reliance on the fast depleting non-renewable conventional energy sources such as petroleum. A large fraction of Brazilian vehicles currently operate on ethanol, rather than on hydrocarbon fuels.

The problems associated with ethanol are due to water contents and corrosive inorganic materials that are dissolved in it. For this reason, corrosion problems are intrinsically more severe with this fuel. The aggressiveness of ethanol to different metallic automotive parts depends on water content ${ }^{(2)}$, chloride concentration ${ }^{(3)}$ and sulphate concentration ${ }^{(4)}$, a 11 of which result from the fuel production process.

Lower concentrations of acetic acid in ethanol solutions may increase the corrosion rate of iron in this medium ${ }^{(5)}$.

Based on these considerations, the corrisivity of the medium on the metallic surfaces may be better controlled by employing suitable corrosion inhibitors in the solution. Many organic compounds were studied in this medium and were found to be effective corrosion inhibitors for low-carbon stee $7^{(6)}$. However, an unsaturated compound such as propargyl alcohol $\left(\mathrm{HCCCH}_{2} \mathrm{OH}\right)$, could give a high protection efficiency in aqueous solutions ${ }^{(7)}$, with the added advantage that it can undergo combustion without forming toxic reaction products.

The aim of the present research was to examine the corrosion rate of low-carbon steel in ethanolic solutions, in the absence and presence of propargyl alcohol as a corrosion inhibitor. The protection efficiency of the inhibitor was evaluated by variation of the specific conductivity of the solutions in contact with the metal. The main parameters studied were: a) water content; b) acetic acid concentration and, c) propargyl alcohol concentration.

\section{EXPERIMENTAL}


The electrical conductivity of the solutions were measured in a $100 \mathrm{ml}$ distilling flask with two angular necks. The conductivity cell was introduced into the solution through one of them. In the other, the metal was suspended and plunged in complete contact with the solution. The system remained closed throughout the measurement.

The metal was a low-carbon steel $(\mathrm{C}, 0.05 ; \mathrm{Si}, 0.04 ; \mathrm{S}, 0.023 ; \mathrm{Cu}, 0.004$ $w t \%)$. The samples were cut from the same sheet in a retangular form $(2.0 \times$ $2.5 \times 0.1 \mathrm{~cm}$ thickness). After mechanical polishing with emery papers, mainly at the edges, the coupons were degreased with carbon tetrachloride, acetone, ethyl alcohol in this sequence, and dried.

The ethanol used in this work, was purified by a distillation process. The temperature control was used to assure the purity level of the distillate. A NMR spectrum was periodically made to control the water contents. A11 solutions were prepared with it.

The propargyl alcohol purity was controlled by gas chromatographic analysis. Periodical distillations were necessary in order to maintain the purity level. The Acetic acid used was Merck p.a., where no purification was necessary. The water added in the ethanol was distilled. All experiments were made in aerated conditions.

Electrochemical measuring equipment consisted of a Philips conductivity meter model PW 9505 and a Philips model PW 9510/60 conductivity cell.

The experiments were made in triplicate and, the coupons were suspended over the solution during the measures. This procedure was taken to assure that the specific conductivity of the solution didn't change.

\section{EXPERIMENTAL RESULTS AND DISCUSSION}

The corrosion process of low-carbon steel in ethanolic solutions, gives mainly ionic species as $\mathrm{Fe}(\mathrm{II})$ or $\mathrm{Fe}(\mathrm{III})$ in solution. As the concentrations of these species increase during the contact of the metal with the aggressive solution, the conductivity of the solutions increase proportionally.

To assure that this occurs, tests were made in all ethanolic solutions to verify the dependence of the specific conductivity with the $\mathrm{Fe}$ (II) concentrations added to them. These solutions containing Fe(II) were prepared 
by dissolving $\mathrm{FeSO}_{4}$ in the same conditions which aggressive mediums were used.

Fig. 1 confirms that, at low $\mathrm{Fe}(\mathrm{II})$ concentrations, the specific conductivity of the solutions increases linearly with the $\mathrm{Fe}(\mathrm{II})$ concentration increases. This behaviour was observed in all ethanolic solutions.

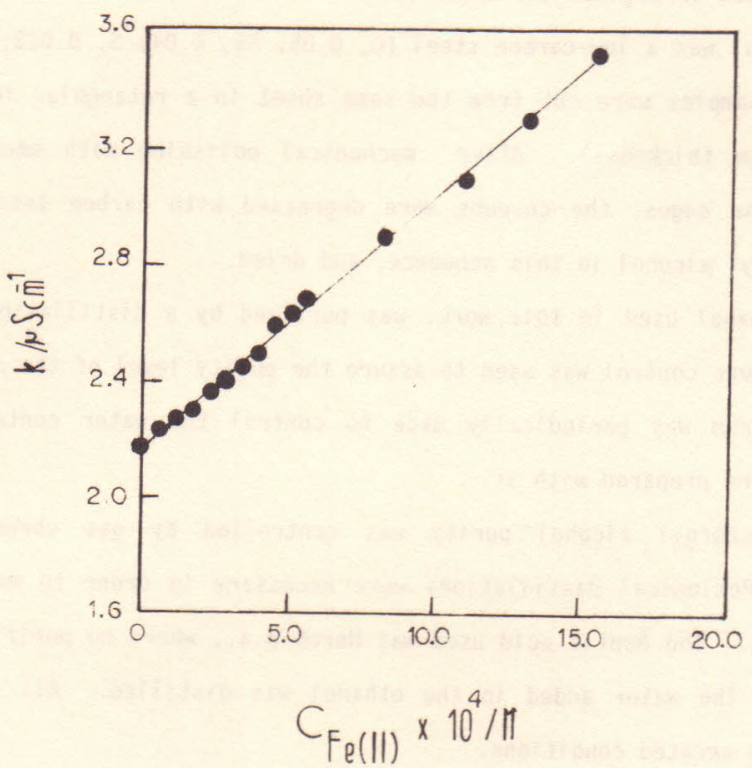

Fig. 1 - Linear correlation between the specific conductivities and $\mathrm{Fe}(\mathrm{II})$ concentrations, added as $\mathrm{FeSO}_{4}$, in $0.1 \mathrm{M}$ acetic acid ethanolic solutions at $25^{\circ} \mathrm{C}$.

With these calibration curves, was possible to deduce that all conductivity variation of the solutions in contact with the metal, were related to the ionic species as $\mathrm{Fe}(\mathrm{II})$ or $\mathrm{Fe}(\mathrm{III})$, formed during the corrosion processes.

Fig. 2 shows the conductivity of pure ethanol in contact with low-carbon steel. As it can be seen, the conductivity of the solution increases quickly with the immersion times, mainly at the begin. After fifteen hours the curve changes completely, with a tendency to a stabilization of the conductivity values. This effect may be related to insoluble compounds that have been formed at the surface of the metal. 


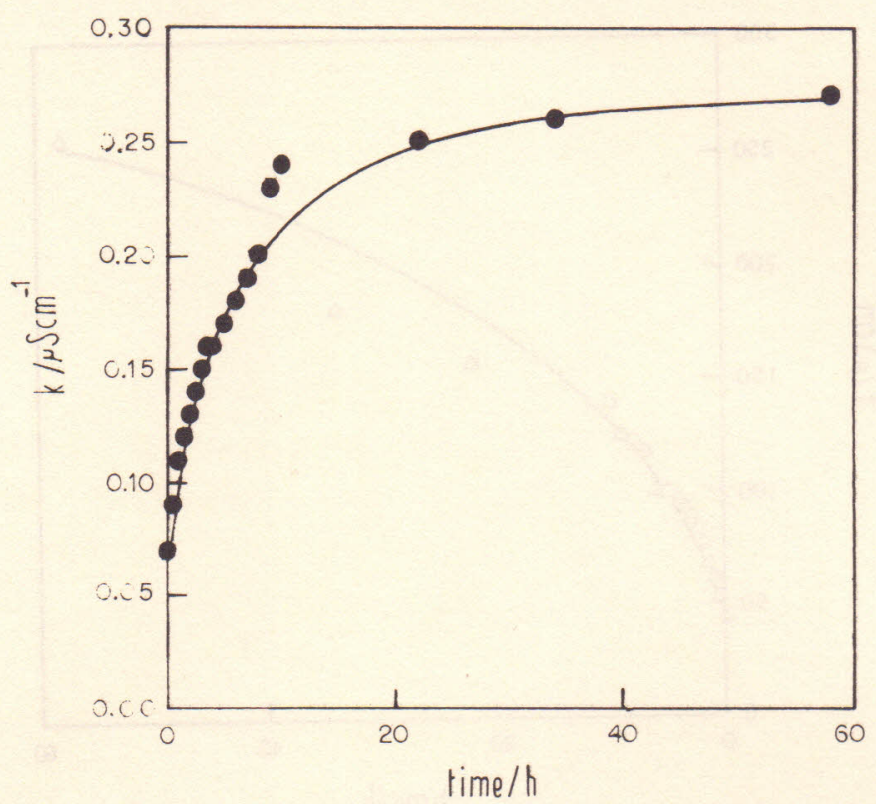

Fig. 2 - Specific conductivity variation of distilled ethanol, without inhibitor, at $25^{\circ} \mathrm{C}$, in contact with low-carbon steel, versus the immersion times.

At more aggressive medium, this behaviour was not observed, as it is shown in Fig. 3. In these tests the metal was in contact with $1.0 \mathrm{M}$ acetic acid ethanolic solutions with $25 \%$ (V/V) of water. As it can be seen the specific conductivity increases continuously with the immersion time. In comparing these two figures, the first conclusion can be taken; the products of the corrosion process, change considerably the corrosion rate. It is clear that there are two different corrosion processes.

EFFECT OF THE WATER CONTENTS IN ACETIC ACID ETHANOLIC SOLUTIONS ON THE CORROSION RATE.

Fig. 4 shows the effect of the water concentration on the conductivity variation of the solution with the immersion times of the metal in $0.01 \mathrm{M}$ acetic acid in: a)distilled ethanol; b)with $10 \%(\mathrm{~V} / \mathrm{V})$, and c)with $25 \%(\mathrm{~V} / \mathrm{V})$ water contents in ethanolic solutions. As it can be seen the corrosion process 


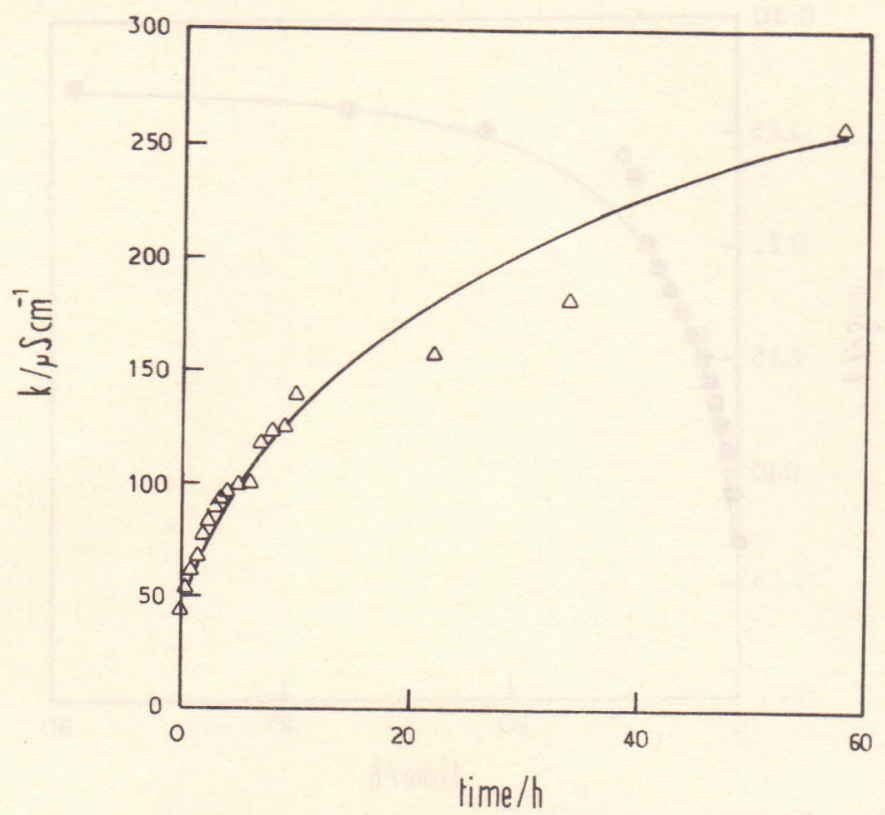

Fig. 3 - Specific conductivity variation of $1.0 \mathrm{M}$ acetic acid ethanolic solutions with $25 \%(\mathrm{~V} / \mathrm{V})$ of distilled water, without inhibitor, in contact with low-carbon steel, versus the immersion times.

increases considerably with the water concentration increase. The peak observed in $10 \%(\mathrm{~V} / \mathrm{V})$ and $25 \%(\mathrm{~V} / \mathrm{V})$ curves correspond to the time where a precipitate of the corrosion products was observed in the solutions. After this time, the decrease in conductivity values may suggest that the $\mathrm{Fe}$ (II) or $\mathrm{Fe}$ (III) species presented in solution at the begin are being removed from solution by formation of insoluble products.

This peak, was not observed in a more aggressive medium as it is shown in Fig.5. In $1.0 \mathrm{M}$ acetic acid, the conductivity changes slowly after twenty hours of immersion, mainly at small water contents. No insoluble corrosion products were observed in these solutions.

EFFECT OF THE ACETIC ACID CONCENTRATION IN ETHANOLIC SOLUTIONS WITH $10 \%(\mathrm{~V} / \mathrm{V})$ OF WATER ON THE CORROSION RATE. 


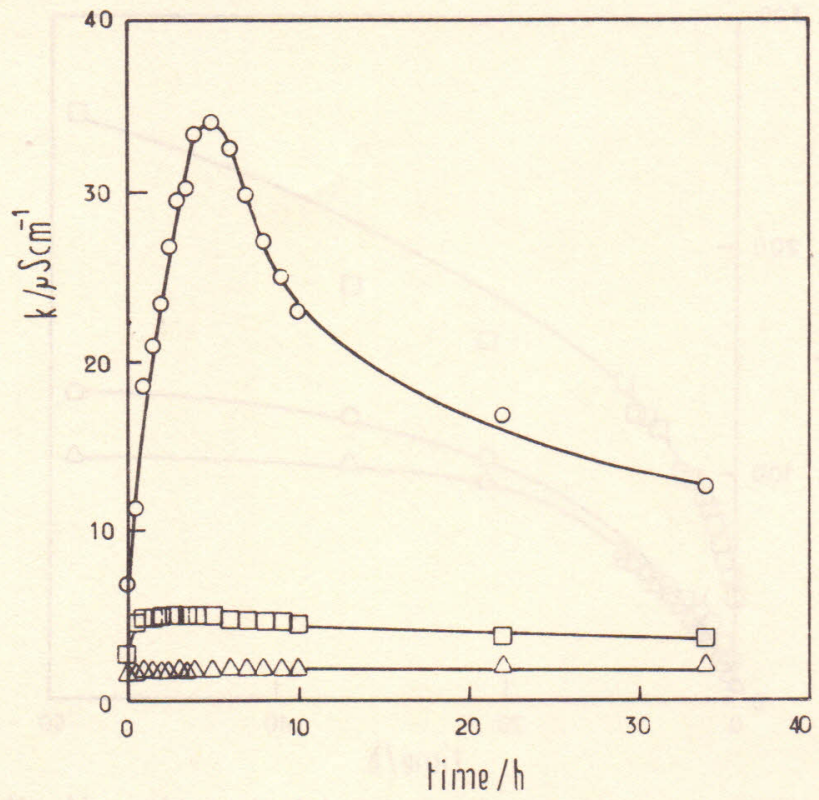

Fig. 4 - Specific conductivity changes of $0.01 \mathrm{M}$ acetic acid ethanolic solutions, with different water contents: $\Delta$-distilled ethanol; with $10 \%(\mathrm{~V} / \mathrm{V})$, and 0 - with $25 \%(\mathrm{~V} / \mathrm{V})$, in contact with the metal versus the immersion times.

The corrosion rate depends considerably of the acetic acid concentration as it is shown in Fig. 6 .

Insoluble products of the corrosion process, were observed at small acetic acid concentrations. When the acetic acid concentration increases, the corrosion rate of low-carbon steel in these ethanolic solutions increases proportionally. The difference in behaviour observed in different acetic acid concentration may be related to the dissolution of the corrosion products at higher acetic acid concentration. This dependence was observed on iron in sulphuric acid methanolic solutions ${ }^{(8)}$.

EFFECT OF PROPARGYL ALCOHOL CONCENTRATION ON THE CORROSION RATE OF LOW-CARBON STEEL IN ETHANOLIC SOLUTIONS.

It has long been known that the corrosion rate of a meta 1 in a aggressive 


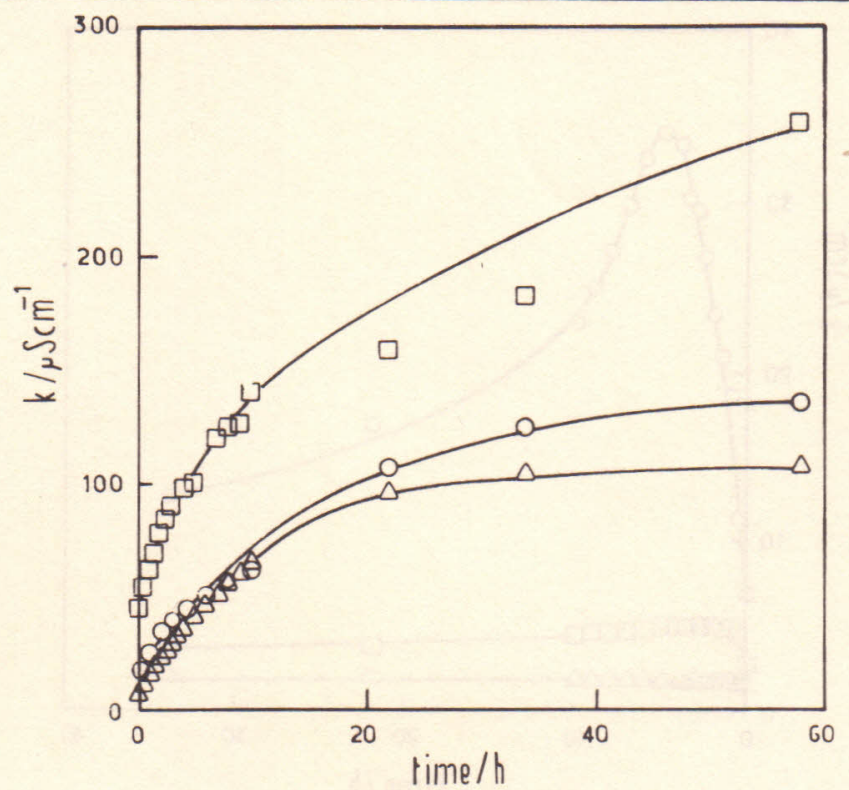

Fig. 5 - Specific conductivity changes of $1.0 \mathrm{M}$ acetic acid ethanolic solutions, with different water contents: $\Delta$-distilled ethanol; 0 with $10 \%(\mathrm{~V} / \mathrm{V})$, and $\square$ - with $25 \%(\mathrm{~V} / \mathrm{V})$, in contact with the metal versus the immersion times.

environment can drop when small amounts of a corrosion inhibitors are added to the system. Fig. 7 suggests that propargyl alcohol can inhibit the corrosion processes which occur when low-carbon steel is in contact with distilled ethanol. The specific conductivity variation of the solutions are lower in the presence of a small amount of the organic inhibitor. This effect may be related to a lower concentration of $\mathrm{Fe}(\mathrm{II})$ or $\mathrm{Fe}$ (III) species that are formed during the corrosion process. It was observed that the decrease of the specific conductivities were not related to the complexing effect of the organic compound with the ionic species. No conductivity variation was observed when propargyl alcohol was added to an ethanolic solution with dissolved $\mathrm{Fe}(\mathrm{II})$. However, it was observed that at higher propargyl alcohol concentration, $5.0 \mathrm{M}$ and $10 \mathrm{mM}$, the conductivity of the solutions increases. This process may be related to the solubilization of the protective film which is formed on the metallic surface ${ }^{(9)}$. 


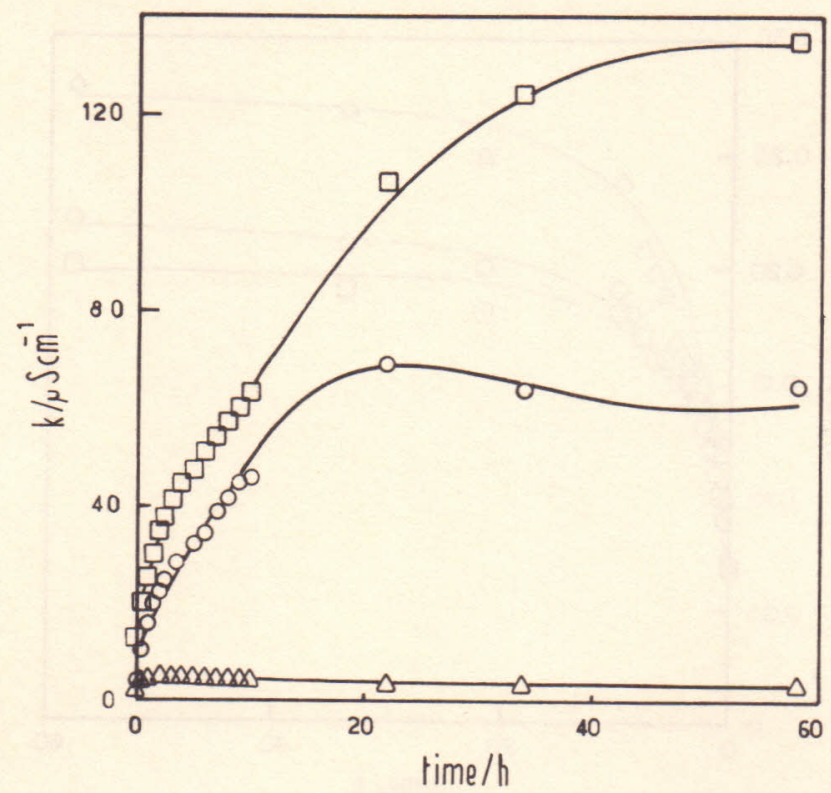

Fig. 6 - Specific conductivity changes of ethanolic solutions with $10 \%$ (V/V) of water contents, and different acetic acid concentrations: $\Delta-0.01 \mathrm{M}$; $0-0.1 \mathrm{M}$, and $\square-1.0 \mathrm{M}$, in contact with the metal versus the immersion times.

On the other hand, in more aggressive solutions, the specific conductivity of them decrease with the propargyl alcohol concentration increase, even at higher values, as it is shown in Fig.8. After ten hours of contact, the corrosion rates change considerably at higher inhibitor concentration. The long time it takes, may be related to the adsorption process of the inihibitor on the metallic surface. This is not a instantaneons one.

The dependence of lower acetic acid concentration on the effect of the inhibitor action of propargyl alcohol can be seen in Fig. 9. When the acetic acid concentration is lower than $1.0 \mathrm{M}$, all solutions show that the inhibitor effect of propargyl alcohol is better at $1.0 \mathrm{mM}$ concentration. At higher inhibitor concentration the specific conductivity increases. This effect may be related to the solubilization of protective film which was formed. 


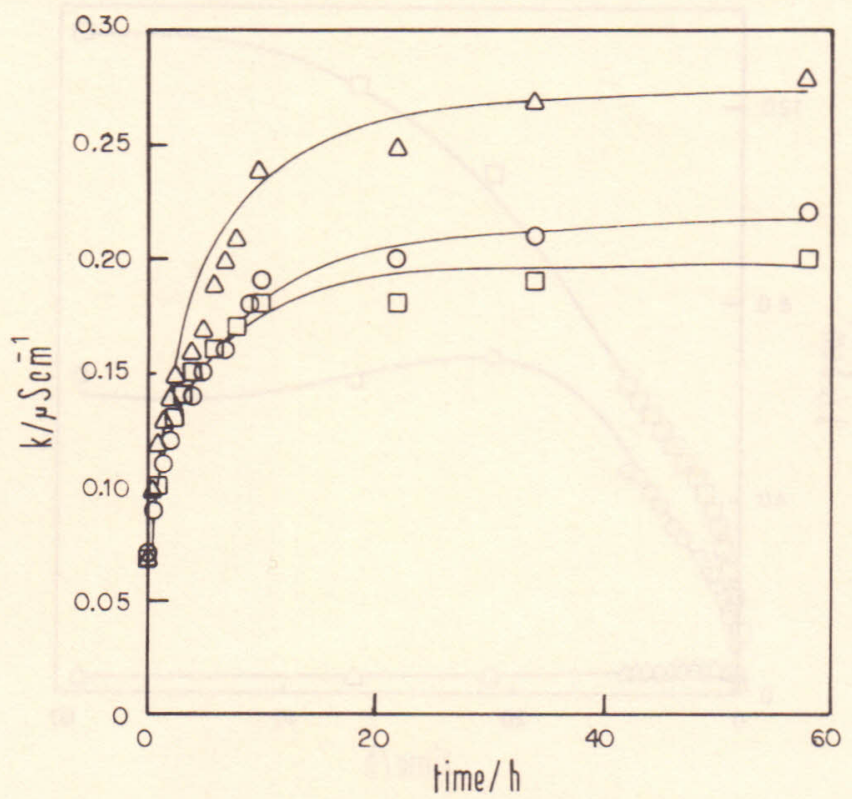

Fig. 7 - Specific conductivity changes of distilled ethanol with different propargyl alcohol concentrations: $\triangle-C_{A P}=$ zero;

$O-C_{A P}=0.3 \mathrm{mM}$; and $\square-C_{A P}=1.0 \mathrm{mM}$, in contact with low-carbon stee 1 versus the immersion times.

CONCLUSIONS

The protection process of propargyl alcohol on low-carbon steel, in ethanolic solutions, was accompained by their specific conductivity measures. This method provides important information related to the behaviour of this metal in different aggressive conditions. The specific conductivity of the solutions changes proportionally with $\mathrm{Fe}(\mathrm{II})$ or $\mathrm{Fe}(\mathrm{III})$ species that are formed during the corrosion processes.

This change dependents on the water and acetic acid contents in the ethanolic medium. The insoluble corrosion products that are formed, decrease the conductivity values of the solutions. This may be considered an evidence that some of the ionic species are disappearing with these compounds. 


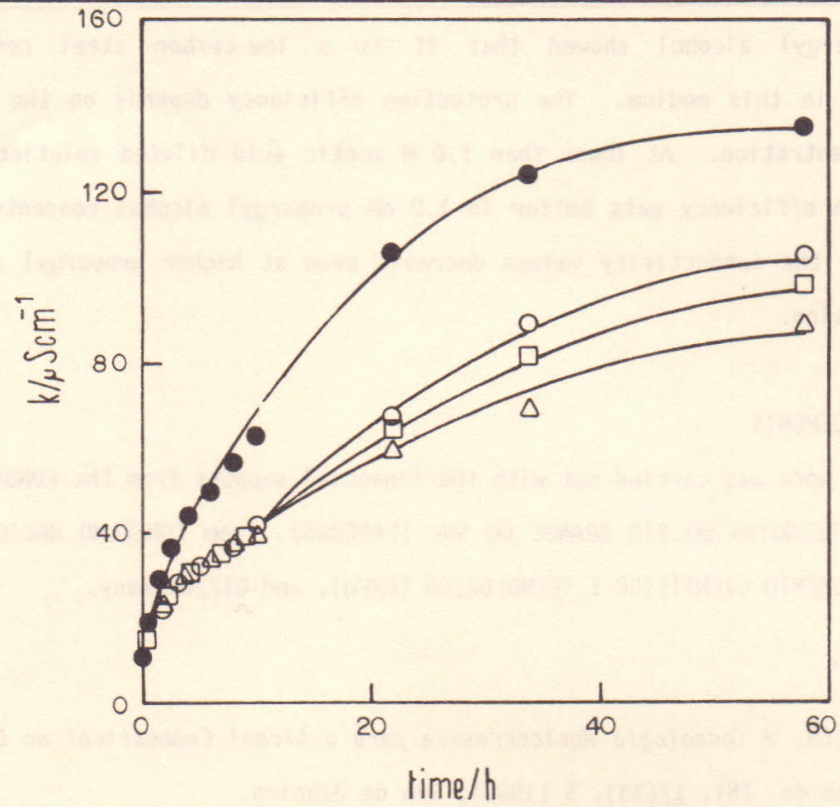

Fig. 8 - Specific conductivity changes of $1.0 \mathrm{M}$ acetic acid ethanolic solutions and $10 \%$ (V/V) of water, with different propargyl alcohol concentrations: $-C_{A P}=$ zero; $\quad 0-C_{A P}=0.3 \mathrm{mM} ; \quad \square-C_{A P}=5.0 \mathrm{mM}$, and $\Delta \cdot C_{A P}=10 \mathrm{mM}$, in contact with the metal versus the immersion times.

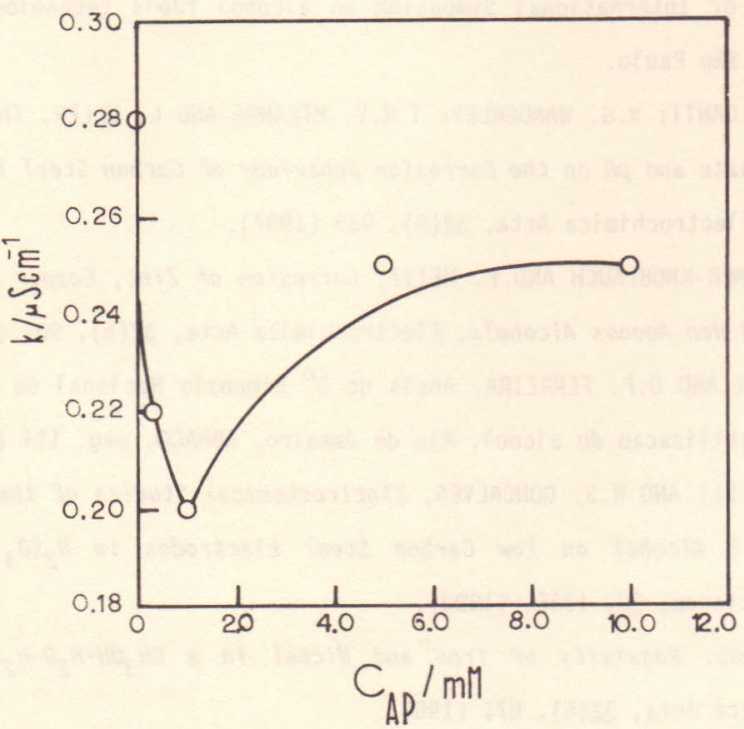

Fig. 9 - Specific conductivity values of the solutions with different propargyl alcohol concentrations in distilled ethanol, after 58 hours in contact with low-carbon steel. 
Propargyl alcohol showed that it is a low-carbon steel corrosion inhibitor in this medium. The protection efficiency depends on the acetic acid concentration. At lower than $1.0 \mathrm{M}$ acetic acid diluted solutions, the protection efficiency gets better in $1.0 \mathrm{mM}$ propargyl alcohol concentration. In $1.0 \mathrm{M}$, the conductivity values decrease even at higher propargyl alcohol concentration.

\section{ACKNOWLEDGEMENTS}

This work was carried out with the financial support from the FUNDAÇÃO DE AMPARO A PESQUISA DO RIO GRANDE DO SUL (FAPERGS), from CONSELHO NACIONAL DE DESENVOLVIMENTO CIENTÍFICO E TECNOLÓGICO (CNPq), and GTZ/Germany.

\section{REFERENCES}

1 - L. ULLER, A Tecnologia Anticorrosiva para o Àlcool Combustível no Brasil, Informativo do INT, 17(33), 5 (1985), Rio de Janeiro.

2 - E. HERTZ, Adv. Corros. Sci. Tech., 4, 149 (1974).

3 - R.R. WIGGLE; Hospadaruk, V.; Styloglov, E. A.; Chu, G. K.; Tallent, W.D., The Corrosivity of Ethanol Fuel Mixtures to Fuel Systems Materials, Proceedings of International Symposium on alcohol fuels technology, vol. 1, 441 (1980), São Paulo.

4 - E. CAVALCANTI; V.G. WANDERLEY; t.R.V. MiRANDA AND L. ULLER, The Effect of Water, Sulphate and pH on the Corrosion Behaviour of Carbon Steel in Ethanolic Solutions, Electrochimica Acta, 32(6), 935 (1987).

5 - U. LECHNER-KNOBLAUCH AND E. HEITZ, Corrosion of Zinc, Copper and Iron in Contaminated Non-Aqeous Alcohols, Electrochimica Acta, 32(6), 901 (1987).

6 - L. ULler and 0.F. FERREIRA, Anais do $3^{0}$ Simposio Nacional de Corrosao na Producao e utilizacao do alcool, Rio de Janeiro, ABRACO, pag. 194 (1983).

7 - A. SPINELLI AND R.S. GONCALVES, Electrochemical Studies of the Adsorption of Propargyl Alcohol on Low Carbon Steel Electrodes in $\mathrm{H}_{2} \mathrm{SO}_{4}$ Solutions, Corrosion Science, 스, 1235, (1990).

8 - J. BANAS, Passivity of Iron and Nickel in a $\mathrm{CH}_{3} \mathrm{OH}-\mathrm{H}_{2} \mathrm{O}-\mathrm{H}_{2} \mathrm{SO}_{4}$ System, Electrochimica Acta, $\underline{32}(6), 871$ (1987).

9 - I.N. PUTILOVA; S.A. BALEZIN AND V.P. BARANNIK, "Metallic Corrosion Inhibitors", p. 169, Pergamon Press, 1960. 